\title{
FUNDAMENTOS DO PENSAMENTO MORAL EM KANT
}

\author{
THE FUNDAMENTALS OF KANTS MORAL THEORY
}

\author{
${ }^{1}$ Adriana Saraiva Lamounier Rodrigues \\ ${ }^{2}$ Diego Manente Bueno de Araujo
}

\begin{abstract}
RESUMO
$\mathrm{O}$ artigo pretende estudar o pensamento moral na filosofia de Immanuel Kant, considerado o primeiro dos filósofos que compõe o movimentoconhecido como Idealismo Alemão, sobretudo na obra Crítica da Razão Prática. Para isto, introdutoriamente, traça os estudos morais com os quais Kant se depara em sua época e as questões fundamentais que tenta responder, além de traços de sua formação que o influenciaram. Logo após, analisa-se o pensamento kantiano propriamente dito, por meio da obra A Ideia de justiça em Kant, de Joaquim Carlos Salgado, marco teórico desta pesquisa. São analisados o postulado da liberdade e sua relação com o dever-ser e a lei moral, as espécies de imperativos, o imperativo categórico e a igualdade, abertura que a teoria moral deixa para a existência do direito positivo e que o autor considera o pilar maior da Ideia de justiça do filósofo prussiano. A metodologia usada na pesquisa é teórica, a partir da análise da obra marco teórico e sua relação com outras publicações referentes ao mesmo tema.
\end{abstract}

Palavras-chave: Idealismo alemão, Razão prática, Pensamento moral

\begin{abstract}
The article intends to study the moral thought in the philosophy of Immanuel Kant, considered the first of the philosophers who composes the movement known as German Idealism, especially in the book "Critique of Practical Reason". To achieve the objective the article begins with the traces of the moral studies at Kants time and its fundamental questions as well as traces of his formation that influenced his writings. Soon after, it analyzes the Kantian thought itself, through the work "The Idea of Justice in Kant", from Joaquim Carlos Salgado, theoretical framework of this research. It will be analyzed the postulate of freedom and its relationship with the sollenand the moral law, the species of imperatives, the categorical imperative and equality, connections that the moral theory makes for the existence of positive law and that the author considers the greater pillar of the Idea of justice from the Prussian philosophers point of ofview. The methodology used in the research is theoretical, based on the analysis of the theoretical framework and its relationship to other publications concerning the same subject.
\end{abstract}

Keywords: German idealism, Practical reason, Moral theory

\footnotetext{
${ }^{1}$ Doutoranda em Direito do Trabalho 'Autonomia Individuale e Autonomia Collettiva' pela Università degli Studi di Roma Tor Vergata em cotutela com a Universidade Federal de Minas Gerais, UFMG - MG, (Brasil). É Advogada. Email: adrianalslr@yahoo.com.br

${ }^{2}$ Mestrando em Filosofia do Direito pela Universidade Federal de Minas Gerais, UFMG - MG, (Brasil).Orientador voluntário da Divisão de Assistência Judiciária (DAJ).E-mail: diego.manenti @ yahoo.com.br
} 


\section{INTRODUÇÃO}

O filósofo Immanuel Kant tentou, em um grandioso e hercúleo esforço, criar um sistema filosófico que partisse do eu como sujeito que pensa, o „Eu-penso ${ }^{\text {ee }}$, e uma realidade que existisse sempre internamente ao sujeito pensante. Toda realidade pensável que tendesse a buscar o universal, ou absoluto, necessitava partir desse „Eu-penso ${ }^{\text {ee }}$, do sujeito racional, sob pena de não abarcar a realidade toda, de não ser universal.

Para isto, o filósofo prussiano biparte toda a realidade, de modo a explicá-la sempre com um método dual: há noumenon e phaenomenon, razão pura e prática, leis morais e jurídicas. Mas porque a bipartição? Isto se deve a uma limitação do ser que pensa. Ele não consegue alcançar nunca a coisa em si, ou noumenon, sendo a ele possível captar apenas fenômenos. Assim, é possível fundamentar a realidade através do ser que pensa e de mais nada fora dele. Afirma Henrique Cláudio Lima Vaz:

(...) tendo operado aquilo que Kant chamava „revolução copernicana ${ }^{\text {ee }}$, isto é, o mesmo sujeito que está envolvido no processo de pensamento da realidade não tem que recorrer a um fundamento exterior a si mesmo; tem que descobrir em si mesmo os títulos para ser sujeito pensante, ou seja, pensar a realidade e justificar a realidade. (VAZ, 2014, p. 141).

É exatamente este o mote central que permeia a filosofia de todo o chamado Idealismo Alemão. Se a obra de Kant não logrou êxito na superação dos seus dualismos, apesar da tentativa de unir razão pura e prática na faculdade do julgamento estético, todo seu esforço foi ponto de partida para os filósofos germânicos posteriores, inclusive Hegel. Kant levantou todas as aporias filosóficas discutidas no Idealismo Alemão e seu esforço, se não pode ser considerado um sistema de filosofia do absoluto, ao menos tenta dar as respostas que o pudesse fechar. Sendo assim, Kant é, sem dúvida, parte integrante do que se conhece como Idealismo alemão. Nas palavras de Lima Vaz:

Podemos situá-lo entre duas datas: 1770, marco inicial do Idealismo alemão, ano em que Kant escreveu a Dissertação De mundi sensibilis atque intellingibilis forma et principiis ( da forma e dos princípios do mundo sensível e do mundo inteligível), em latim, como era costume, na qual lança as primeiras linhas do seu criticismo transcendental, e 1831, data convencional do término do Idealismo alemão com a morte de Hegel. (VAZ, 2014, p.138).

O pensamento moral de Kant tenta responder a uma pergunta fundamental: como fundamentar um comportamento moral universal no sujeito que pensa, no Eu-penso, e não fora dele, como se fez até a modernidade filosófica. Parte daí todo o desenvolvimento da razão prática, 
aquela que possuí o princípio a priori da ação, ou seja, a lei moral. E também parte da doutrina da moral as condições de possibilidade da existência do direito positivo e de sua Ideia de justiça, fundada na liberdade e na igualdade.

A partir de agora o estudo se volta para o pensamento moral de Kant, com dois pequenos intróitos sobre a modernidade filosófica e alguns aspectos da formação da convicção do filósofo prussiano.

\section{O PROBLEMAMORAL NA FILOSOFIA MODERNA}

A secularização do mundo e o domínio da natureza através das ciências da física e da matemática trazem à filosofia prática moderna um problema a ser resolvido. $\mathrm{O}$ fundamento de obrigatoriedade da moral, antes extraídos de esferas transcendentes agora devem ser retirados do homem. Em outras palavras, as respostas até então dadas para o comportamento moral (sobretudo pela filosofia medieval) já não são mais consideradas satisfatórias. A autoafirmação do homem como centro do universo, advinda do Humanismo e desenvolvida na Ilustração, não comporta mais os fundamentos de um absolutismo teológico que a tudo validava.

Neste contexto, segundo Wolfgang Kersting podem-se destacar três respostas principais dadas pela modernidade "a fim de colocar a práxis social de justificação sobre um novo patamar teorético-obrigacional"(KERSTING, 2009, p. 148). Diz, ainda o mesmo autor, serem elas: "a concepção Hobbesiana do voluntarismo contratualista; a Humiana da naturalização da moral e da socialização do Direito e, em terceiro lugar, a concepção kantiana das leis da liberdade dadas pela razão"(KERSTING, 2009, p. 148).

Hume, à guisa de sua epistemologia empirista, procura o fundamento de obrigatoriedade da moral em algo que possa ser medido na experiência, de que se possua percepção sensorial. Com isso, baseia a Moral no sentimento e o Direito no interesse. Haveria na natureza humana um sentimento responsável pela moral, capaz de, estimulado pelas percepções do mundo, elaborar concepções de aprovação ou desaprovação. Este sentimento não é, de forma alguma, universalista, pois que depende umbilicalmente da experiência daquele que sente, ou seja, de um relacionamento interpessoal baseado em emoções fortemente entrelaçadas para que aconteça o comportamento moral e sua validade. Sobre isso ainda Wolfgang Kersting:

Mas, quando os limites de intimidade social são extrapolados e a força das emoções diminui, de forma que as pessoas só se relacionam entre si como estranhos, a razão 
moral perde sua competência. Ela nunca consegue tatear de forma universalista. (KERSTING, 2009, p. 148).

A concepção humiana leva a uma consequência lógica: se o comportamento moral depende única e exclusivamente deste sentimento, baseado na experiência de intimidade nas relações sociais; cogitá-la cogente é somente uma quimera. A esfera da moralidade só tem, então, capacidade onde houver a vivência efetiva daquele sentimento natural ao homem.

Thomas Hobbes, por sua vez, enxergará a obrigatoriedade da moral fundamentada no contrato social. Assim como Deus criou o homem e o mundo físico por intermédio de sua linguagem, seu fiat, o homem cria o mundo jurídico-moral em que está inserido por meio de uma linguagem obrigacional, um contrato, em última análise, a criação de um Estado. O ser humano abre mão de parcela da sua liberdade, limitando-a por leis que ele mesmo criou. Esse "poder criador" do ser humano origina uma pessoa, o Estado(Leviatã), que será uma espécie de mau necessário à convivência pacífica em sociedade. Diz Wolfgang Kersting:

\begin{abstract}
A prerrogativa de obrigatoriedade do mundo das normas não tem qualquer sustentação ontológica objetiva; moral e direito são, em Hobbes, invenções coletivas resultantes de uma creatioexnihilo teorético-obrigacional. (...) $\mathrm{Na}$ teoria da obrigatoriedade, a pessoa assume um papel divino de criador. Assim como Deus criara o mundo natural, a pessoa cria o mundo moral separado do mundo natural, não relacionado a este. (KERSTING, 2009, p.150)
\end{abstract}

Embora recorra à imagem teológica do criacionismo, Hobbes dá ao homem o poder criador do mundo normativo, ou seja, jurídico-moral a partir de um vazio, de um nada.

Conclui-se então, que nele não há ontologia; o que existe é apenas uma linguagem obrigacional, chamada contrato, criada pelo homem e que a ele servirá. É importante notar que o valor que informa a criação é tão somente a vontade de preservar a liberdade dos criadores, tolhendo parcela dela.

Kant dialoga com estas duas concepções de moral, ou melhor, com estes dois tipos de fundamento da obrigatoriedade do comportamento humano para refutá-las. Para o filósofo prussiano a moral tem caráter universal e necessário, fundamentada nos postulados de igualdade e liberdade da razão pura prática. É este o pensamento objeto do qual este estudo se ocupará em diante. Mas antes é preciso tecer algumas linhas sobre a influência do cristianismo, mais especificamente do pietismo, no pensamento moral de Kant.

\title{
3. KANT E A DOUTRINA PIETISTA DE SPENER
}


Vinculado ao pensamento da Reforma Protestante de Lutero, o pietismo alemão, cujo maior expoente foi o pastor Philipp Jakob Spener, traz à teologia uma adequação maior às exigências da modernidade. O teólogo valoriza, sobretudo, os ensinamentos contidos na Bíblia e a experiência prática de vivência subjetiva do cristão daqueles valores. A religião torna-se menos oficial e mais subjetiva, de leitura e experiência daquilo que é ensinado pelas Sagradas Escrituras.

A doutrina pietista pode ser assim sintetizado. Em primeiro lugar está o sacerdócio universal dos cristãos, em que todos participam dos serviços religiosos, independente decargos ou posição na Igreja. Dá-se especial atenção ao cultivo individual da vida espiritual, ou seja, à oração e a abstinência de práticas libertinas como a prostituição, o consumo excessivo de bebidas alcoólicas, a moderação nas vestes e nos alimentos. Para isso, o cristão deve viver de forma disciplinada, observando sempre as regras contidas na Bíblia, de forma rigorosa. É o Livro Sagrado que contém autoridade superior à de qualquer outro texto. Por fim, somente a experiência é o fundamento da certeza de uma vida cristã, ou seja, apenas um cristão regenerado, que vive a experiência da abnegação, é um verdadeiro teólogo.

Daqui pode-se extrair, grosso modo, pelo ou menos duas coincidências com a filosofia de Kant. Tal como a doutrina pietista o filósofo prussiano dá atenção especial ao sujeito. É nele que reside o conhecimento; um objeto é tal como é percebido em sua razão, através do filtro das categorias (revolução copernicana de Kant). Além disso, e o que interessa mais á filosofia prática, pode-se dizer da rigidez da obediência as regras. Seguir as leis é condição sine qua non do cristão; os imperativos categóricos são comportamentos necessários dados pela razão pura prática.

Ferdinand Alquié, na introdução á edição da "Crítica da razão prática” publicada pela Presses Universitaires de France, afirma:

\footnotetext{
da doutrina de Spener, promotor do pietismo, Kant parece reter a concepção rígida da lei, o sentimento de dificuldade do dever, e sobretudo a ideia de que o princípio da moral e da religião não está no entendimento, mas sim na vontade (ALQUIÈ, 2003 , p. 4, tradução nossa) ${ }^{1}$
} ${ }^{1}$ No original: De la doctrine de Spener, promoteur du piétisme, Kant semble avoir retenu la conception rigide de la loi, le sentiment de la
difficulté du devoir, et sourtout l"cidée que le príncipe de la morale et de la religion n“est pas dansl"entedement, mais dans la volonté).

Embora Kant tenha influência clara do pietismo em seu pensamento, sobretudo na parte moral, a ele não se limitou. Enquanto o pensamento teológico continua a encontrar em 
Deus todo fundamento da ação humana obediente às leis, portanto na esfera transcendente, Kant desloca o motivo do agir moral para a razão do homem. O que no pietismo é sobrenatural tornase na obra do filósofo kantiano supra-sensível, ou seja, transcendental. No caso da moral fundamentado na razão pura prática e seu motor de ação, o imperativo categórico.

\section{OS FUNDAMENTOS DA MORAL EMKANT}

A partir de agora serão analisados todos os aspectos da filosofia prática de Kant, no que concerne à moral.

\subsection{Dever ser e liberdade}

Dever ser (Sollen) e liberdade são dois conceitos centrais e umbilicalmente correlacionados na filosofia moral de Kant. Aliás, é por meio destes dois conceitos bem como da relação entre eles que o filósofo responde à questão principal da moral crítica: a natureza universal da obrigatoriedade da ação moral. Diz Salgado:

\footnotetext{
Quando a ação se torna obrigatória, vale dizer, no sentido etimológico-semântico, vinculada a um dever ser? Kant encontra a expressão "necessidade da ação" para expressar o dever ser, ou, com isso, a vinculação necessária entre a ação e o dever ser como norma. (SALGADO, 2012, p. 112)
}

Quando decorrente da razão pura prática toda ação é necessariamente vinculada a um dever ser, ou seja, uma norma, regra de comportamento. Se o agir é moral, diga-se, consectário da razão, corresponderá sempre ao prescrito naquele dever, criada por esta mesma razão que é autônoma, ou seja, que coloca normas para si mesma, portanto livre. Em outras palavras, quando a ação tem como sua finalidade e seu motivo a própria regra moral, o prescrito no Sollen torna-se consequência necessária, a exemplo das leis de causa e consequência estabelecidas na causalidade, sem contudo, com elas se confundir.

Há, aparentemente, uma circularidade de pensamento que pode levar a um reductio ad infinitum. Contudo, explica-se. O postulado da liberdade é causa incausada, primeira causada ação moral. É a liberdade, ou seja, o determinar-se da vontade pura (autonomia), que cria as leis que ela mesma deve seguir nas suas ações. A liberdade dá ao homem racional a capacidade de criar o Sollen. Como seria, então, racional agir de maneira contrária às leis que a própria razão erigiu? Trocando em miúdos, como seria racional agir contra a própria razão? É isto o que 
explica, para Kant, o agir racional, livre, ser sempre consequência necessária do arcabouço normativo chamado „dever ser“. Nas palavras de Salgado:

\begin{abstract}
A capacidade de a vontade pura determinar-se, que é exatamente o que se chama liberdade em sentido positivo, conduz-nos ao Sollen, que é o momento da vontade enquanto já determinada sem interferência de qualquer causa externa. Nesse sentido o dever ser é um dever ser puro que expressa uma necessidade absoluta, incondicionada e, por isso, vincula incondicionadamente. (SALGADO, 2012, p. 113)
\end{abstract}

Cabe distinguir, como faz Salgado em seu livro, entre duas significações de dever ser. Um primeiro, sentido amplo, é o Sollen como ideia, modelo. Diz, à moda platônica, como deve ser a realidade. Em Kant se torna regra. Um outro, sentido estrito, próprio da filosofia kantiana, que se restringe à ação moral. Significa imposição da regra criada pela liberdade.

O direito positivo se vale de regras de dever ser, porém em sentido amplo. Vale dizer, a forma do direito é um Sollen. Porém, este não é necessário, pois leva em conta motivos contingentes em sua elaboração, não puramente racionais. É que o homem é dotado de razão, mas vive em meio aos fenômenos. Pode agir inclinado à paixões estranhas ao estritamente racional. Os imperativos de direito não são categóricos como os da moral, e, sim,hipotéticos. A norma jurídica coloca um objeto fora de si mesma a ser alcançado. $\mathrm{O}$ homem necessita de regras por ser livre, inclinado às paixões. Justamente por ser livre possui vontade, capacidade criadora de regras. Daí a explicação da existência do Sollen. Embora as regras direito não possuam essa necessidade da ação coincidente com a sua prescrição, ele determina-se por realizar a liberdade, portanto, sempre vinculado à um imperativo categórico, dever ser em sentido estrito. Explicita Salgado:

Como imperativo hipotético aparece o direito numa zona periférica. O fundamento e o destino do direito são a liberdade e o seu imperativo, enquanto considerado nos seus princípios a priori ou com a ideia, é o imperativo categórico.(SALGADO, 2012, p. 116)

O dever ser, consectário lógico da liberdade, entendida como autonomia da vontade, é o que fundamenta o pensamento moral de Kant. Moral universal, necessária, princípio e finalidade da ação em si mesma. Nos dizeres de Salgado:

A liberdade aparece aqui como o ponto central de toda reflexão na esfera do dever ser ou do agir, de que ela é o fundamento último, pois "prático é tudo que é possível através da liberdade", que, entretanto, só se revela a partir da lei moral (SALGADO, 2012, p. 117) 


\subsection{A Lei Moral: Princípio, Máxima E Lei}

Este tópico ocupa-se de distinguir três importantes conceitos da filosofia kantiana, bem como de explicitar a relação entre eles. Principio é um conhecimento que fundamenta outro. O filósofo prussiano busca na sua filosofia prática, sobretudo, encontrar e justificar o fundamento absoluto, ou seja, último, da moralidade. Procura, então, o princípio máximo da moral.

Na esfera da filosofia prática princípio é a última razão do agir. Segundo Kant, é a "representação das leis" por meio das quais o homem age. De natureza racional, o homem é o único ser conhecido capaz de agir por representação de leis, de deveres, ao contrário dos animais, que agem segundo as leis mesmas da natureza, o instinto. Sobre isso afirma Salgado:

Agir segundo representação de uma lei é introduzir no mundo o elemento vontade e, com isso, a liberdade. Esse princípio prático (a representação de uma lei que informa a razão) quando é fim em si mesmo, é absoluto e, por isso, também objetivo, que em Kant tem o significado de universal. (SALGADO, 2012,p. 118).

O princípio do agir humano está ancorado no postulado da liberdade; sem ele não seria possível imaginar a moralidade como ela é para o homem: ter-se-ia, por um lado, ou razão perfeita, vontade santa, plenamente livre, que agiria segundo as leis mesmas da moralidade de maneira absolutamente necessária ou, por outro, um animal irracional agindo de acordo com seu instinto (lei da natureza). Assim sendo, as leis morais são princípios da razão, não decorrem de experiências da sensibilidade. São, pois, a priori, absolutas, universais (válidas para todo ser racional existente, em qualquer tempo e lugar). São juízos sintéticos a priori.

Kant chama de máxima os princípios subjetivos da ação (individuais, que podem estar ou não de acordo com o objetivo), derivada dos princípios objetivos da ação. Estes últimos são divididos em três. Primeiro o técnico, que dá conta do emprego do meio adequado e eficaz para se alcançar uma meta proposta. Segundo o da prudência, que impulsiona a busca da felicidade². Por último está o da moralidade. Todos os três são princípios da razão: a ela cabe buscar meios técnicos satisfatórios, assim como intentar a felicidade e, obviamente, é responsável pelo agir moral.

\footnotetext{
${ }^{2}$ De maneira resumida, felicidade em Kant (Glückseligkeit) é satisfazer a totalidade das inclinações, em grau, duração e variedade destas).
} 
O princípio técnico é condicionado ao fim a que almeja. $\mathrm{O}$ da prudência vincula-se ao desejo e ao caráter de quem age. $\mathrm{O}$ da moralidade, e somente ele, prescinde dos desejos, vale independentemente de coincidência entre eles. É, também, desvinculado de qualquer finalidade, pois que fim em si mesmo. O princípio da moralidade é incondicionado, absoluto, ideia da razão. Há entre eles uma relação de subordinação. O técnico se subordina ao da prudência, que se subordina ao da moralidade. Explica Salgado:

Aqueles princípios (técnicos e da prudência) são, portanto, duas vezes condicionados: porque se sujeitam, na sua aplicação, aos desejos e aos fins que querem realizar e porque se sujeitam a uma lei absoluta e incondicionada, ou seja, ao supremo princípio da moralidade.(SALGADO, 2012, p.119)

Máximas podem ser materiais, com fim externo, ou formais, relacionadas somente à liberdade. As matérias nada têm a ver com a ação moral do homem. A máxima é um princípio de ação, não somente o impulso de agir que qualquer animal possui. Media a lei moral em abstrato e o comportamento concreto do sujeito. Quando não é universalmente válida pode ser boa ou má. A máxima passa a ser lei quando coincide com o princípio de ação moral objetivo, universalmente válido, portanto, bom sempre. Somente as máximas formais podem gerar leis,uma vez que as matérias são adquiridas por indução, a posteriori. Se coincidente com o

princípio objetivo a máxima formal torna-se lei, vale como lei.

É a máxima formal a priori que indica a ação por dever, uma "reverência à lei moral" (expressão de Salgado). Obedecer a lei moral, então, vem de um sentimento humano de estar subordinado à ela, de dever respeitá-la, de querer agir conforme o por ela disposto.

Essa vontade só pode ser humana, pois o sentimento de querer agir de acordo com a lei não pode vir de uma vontade pura: esta coincide com a lei sem deixar sobras. Nas palavras de Salgado:

\footnotetext{
A reverência a lei, despertada pelo conhecimento da lei, leva o ser racional a aceitála e a fazê-la sua máxima. A ação deve realizar a máxima, como seu princípio subjetivo. A máxima deve realizar a lei, como seu princípio objetivo. Assim, a lei é o critério objetivo de validade da máxima; a máxima, o critério subjetivo de julgamento da ação (SALGADO, 2012, p. 120).
}

Depois de tudo isso, formula-se um conceito de lei: "é um princípio objetivo, vale dizer, universal"(SALGADO, 2012, p. 122). Lei, no sentido mais rigoroso do termo, sejam aquelas da natureza, ou estas da liberdade, valem universalmente, são objetivas, fatos da razão, $a$ priori. No caso da lei moral, diz-se universal não somente por independer de qualquer dado de sensibilidade na sua formulação, mas também porque vale para todos oshomens indistintamente, 
numa retomada clara do princípio da igualdade de todos perante a lei, hoje pela doutrina e pela teoria do direito chamado, comumente, de igualdade formal.

\title{
4.3 A lei moral como “fato da razão" e o imperativo
}

A lei moral é uma proposição sintética a priori: não é deduzida nem induzida de nenhuma experiência sensível. Vem de maneira direta da razão, submetendo de imediato a vontade. É fato porque a razão tem natureza legisladora, ordenadora, portanto dela é como um "fruto natural". Sendo assim, o dever ser originado na lei na verdade é um querer válido "para todo ser racional, desde que a razão nesse ser possa agir sem obstáculo" (SALGADO, 2012, p. 123).

No pensamento kantiano razão pura prática, liberdade e vontade pura são sinônimos. Explica Salgado:

\begin{abstract}
O querer é idêntico ao ordenar, ou a liberdade atuante (vontade livre) é lei racional; não é sem razão que kant define o "fato da razão" ora como a consciência da lei moral (Mann kann das Bewusstsein dieses Gründgesetze sein Faktum der Vernunft nennen), ora como consciência da liberdade (dieses Faktum- da razão- mit dem Bewusstsein der Freiheit dês Willens unzertrennlich verbunden), como momentos dialeticamente considerados (no sentido hegeliano), mesmo porque liberdade e lei moral referem-se uma a outra (Freiheit und unbedingtes praktisches Gesetzweisen also wechselweise aufeinander zurück).(SALGADO, 2012, p. 123)
\end{abstract}

Salgado interpreta a relação entre lei moral e liberdade como momentos em uma relação dialética à maneira hegeliana. São então momentos diferentes de uma mesma coisa, pontos de vista distintos do mesmo fato que, reconciliando os dois será absoluto (também no sentido hegeliano), ou melhor, universal atendo-se à filosofia de Kant ${ }^{3}$. É a consciência da liberdade que possibilita a cópula entre sujeito e predicado, formando um juízo sintético a priori, o imperativo categórico.

A liberdade é um postulado, ou seja, não precisa ser provada (como a matemática, é passível apenas de demonstração). A razão prática sabe que é livre e isso basta, ela tem a capacidade de agir de diferentes formas, torna o homem diferente dos demais animais. Assim, tem como principal função a moralidade, ou seja, a criação de regras a priori e universalmente válidas para o agir humano.

\footnotetext{
${ }^{3}$ Universal em kant e absoluto em Hegel são conceitos completamente distintos. Vai aqui somente uma adequação a um termo kantiano. Em verdade, são sinônimos. Todos absolutos, a priori e para todo homem válido.
} 
Decorrente da liberdade que é, o caráter legiferante da razão prática também não precisa de demonstração. Resta uma pergunta: como uma razão pura pode ser prática? Ou melhor, como uma razão que cria regras a priori e universais pode agir no mundo da sensibilidade e das contingências? Kant responde que ao atuar no mundo natural o homem o faz sobre fenômenos, ou seja sobre percepções que o sujeito tem das coisas em si mesmas. Estes fenômenos estariam condicionados à transcendentalidade do sujeito, isto é à própria razão pura. Somente assim uma razão pura pode lidar com as intempéries do mundo natural.

Esta lei moral, considerada em si mesma, não é um mandamento. Ela é universal, pois que a priori e válida para todos. Por este motivo é formal, não aceita qualquer conteúdo material. Se ela é válida para todo ser racional inclui em seu bojo a vontade pura, santa, e aquela própria do homem, sensível e inteligível, inclinada ao natural, que pode ser desviada.

Como imperativo (expressão do dever ser), mandamento, a lei moral só aparece para o homem. Não há sentido na lei “mandar” no agir da vontade pura se ele é a própria lei moral.

Com isso, Kant quer enfatizar que a lei moral só tem sentido para homem enquanto ser de natureza racional. Nos dizeres de Salgado:

É por pertencer o homem ao mundo inteligível, que pode formular e seguir a lei moral que, em princípio, nada tem a ver com a perte sensível que compõe esse ser bifurcado. Digo "em princípio" porque, como lei moral em si, tem ela fundamento exclusivamente na razão. Entretanto, quando se trata da formulação e aplicação para um ser que não é somente racional, mas também sensível, a lei moral manifesta-se como um dever ser que se expressa por um imperativo.( (SALGADO, 2012, p. 125)

Tudo isso quer dizer que para ser aplicada a um ser também sensível a lei moral manifesta-se como um mandamento, um Sollen, um imperativo. Daí duas implicações: a lei moral em si é um "fato da razão", um juízo sintético a priori, não está na sua natureza ser um mandamento; ao se manifestar para o homem como imperativo ela subordina a parte sensível dele à racional. Ou seja, há um predomínio da razão no homem.

Vale ressaltar que a lei moral é uma só: apenas aparece para o homem como imperativo. Do ponto de vista humano é a lei motivada pela vontade de cumprir o dever (expressão do Sollen). Esse sentimento de respeito à lei é necessário, pois dada a natureza dupla do ser humano ela não poderia se cumprir espontaneamente (assim seria somente se o ser racional possuísse vontade pura). Então, para o homem a lei moral se apresenta como imperativo, mandamento.

Kant se vale do exemplo de Cristo. Embora tenha natureza divina, Jesus é Deus encarnado, homem. Sendo assim, se submeteu também ao sensível. Para ele a lei moral sempre 
se mostrou como Sollen. Se ele sempre agiu de forma moral, se sempre cumpriu a lei, foi porque teve o sentimento de dever cumpri-la, submeteu suas paixões ao lado racional. Esta argumentação de Kant é coerente com diversas passagens bíblicas em que Cristo admite ser tentado pelas inclinações sensíveis. A mais famosa e dramática delas é a narrada em Lucas capítulo 22, versículo 42, quando Jesus, sabendo que era chegada a hora de cumprir seu destino no mundo, ou seja, o sacrifício de morrer crucificado, por um instante clama a Deus que dele tirasse aquele fardo, vontade clara de sua inclinação sensível : "Pai, se queres, afasta de mim este cálice, entretanto, não seja feita a minha vontade, mas o que Tu desejas”(BÍBLIA, 1994).

O imperativo é, então, a fórmula mandamental da lei da razão. Seu modo de expressão é o termo de ligação dever ser. Sobre isso, Salgado:

Ao expressar-se por um dever ser, o imperativo revela uma relação de uma lei objetiva com uma vontade que não se determina necessariamente pela lei, em virtude de sua constituição subjetiva. Por isso, aparece como força coativa. (SALGADO, 2012, p. 127)

A coação existe para tornar a lei moral necessária também no âmbito do sensível, para constranger o homem a ter o sentimento, o dever de cumpri-la. Inibe, assim, comportamentos desviados. O homem percebe a lei moral como coativa.

Em função da existência da sensibilidade, o homem cumpre a lei por meio de uma máxima, que pode coincidir ou não com a lei moral. Então intervém o imperativo categórico como critério de aferição de validade do princípio subjetivo que movei aquela ação. Diz Salgado:

\begin{abstract}
A rigor poder-se-ia dizer que há uma forma de lei da moralidade totalmente formal, sem qualquer conteúdo de ação, que se dirige à forma da ação, de como se deve praticar a ação para que ela possa ser moral, e uma forma que aparece regendo a própria ação através da máxima. Neste caso, a aferição de que a máxima possa ser erigida em lei moral, portanto válida para todo ser racional, é de total responsabilidade do sujeito que age. (SALGADO, 2012, p. 128)
\end{abstract}

A lei moral, então, rege a máxima que desperta a ação. Mas por ter conteúdo somente formal, ela não aceita exemplos ou contingências de motivos ou finalidades. Para ser moral o comportamento tem de poder ser erigido à máxima universal, em total acordo com a lei moral. O que afere esta validade é o chamado imperativo categórico.

\title{
4.5 Os Imperativos e suas Espécies.
}

Salgado (2012, p. 128) explica que o imperativo é "uma forma de expressão da lei para o ser humano" e que a lei moral, em si mesma, não é imperativo. A lei moral só se torna imperativo quando traduz um mandamento para o ser humano. Nas palavras de Joaquim Carlos 
Salgado, "esses princípios são sempre modelos de ação, por isso, imperativos, que se impõem a nós aparentemente como algo estranho e externo, embora o que é externo são os impulsos sensíveis" (SALGADO, 2012, p. 129).

Assim, só a transformação da lei moral em dever ser (Sollen) para o ser dotado de razão e sensibilidade, liberdade e necessidade, ou seja, para o ser humano. O dever ser não teria razão de existir se fosse destinado a um ser puramente racional, seria inútil um imperativo a um ser que já pratica exatamente aquilo que deve, por possuir uma vontade totalmente desvinculada de impulsos e inclinações, tal ser realizaria a lei moral sempre e absolutamente.

Não há uma automática realização do princípio da moralidade porque o homem não é um ser puramente racional, dado que nem sempre "domina completamente suas paixões" (PATON apud SALGADO, 2012, p. 129). Tal entendimento vale para todos os princípios objetivos.

Sob a forma de necessidade, o Gebot (mandamento) ou o Imperativ (imperativo) se manifesta em um ser racional. Não há distinção entre mandamento e imperativo, uma vez que o imperativo é a própria fórmula do mandamento, ou seja, é o mandamento expresso em linguagem.

A vontade pura cria o valor e é algo interno. Trata-se do bem mais alto. Assim, o bem é a própria determinação da vontade a partir de si mesma. Destaca Salgado:

Outras espécies de bem existem, embora condicionada ao bem supremo, à boa vontade. Isso significa que o ser racional deve buscar a sua felicidade. Esse bem, porém, está condicionado ao bem moral, vale dizer, não pode a sua realização oporse à do bem moral. Uma situação em que se realizam tanto o bem moral como a felicidade é obviamente melhor do que aquela que realiza tão só o bem moral (SALGADO, 2012, p. 130).

Felicidade, aqui, não se confunde com finalidade da ação moral, assim como o é em Aristóteles (eudaimonia). Aliás, sequer os conceitos dessas „duas felicidades ${ }^{\text {¿e }}$ se confundem.

O que se constata é que, para Kant, o bem moral não é felicidade, mas é com ela compatível. O bem moral não tem finalidade, não visa à felicidade, pois é um fim em si mesmo.

Toda ação pode ser boa para um fim, boa para o sujeito que a realiza e boa em si. O valor dessas ações é determinado pela destreza, felicidade e moralidade, aos quais corresponderão aos imperativos.

Aqui se verifica a classificação dos imperativos. Quanto à finalidade, tem-se o imperativo hipotético (visa a um fim) e o imperativo categórico (fim em si mesmo). Já quanto a quem deseja o fim, tem-se o imperativo problemático (fim possivelmente almejado por alguém) 
e o imperativo assertório (fim naturalmente desejado por todos). Por fim, na classificação segundo o grau de coação, têm-se os imperativos técnicos (regras de destreza), os imperativos pragmáticos (conselhos de prudência) e o imperativo categórico (leis da moralidade).

Em relação à classificação de imperativos segundo o grau de coação que se pode exercer na consciência do ser humano e a sua inter-relação com as outras classificações, Salgado esclarece:

\begin{abstract}
Em resumo, o imperativo técnico é o princípio da destreza, na medida em que define a ação (ou o bem) como meio útil ou adequado a determinado fim (por isso chama hipotético), que alguém pode querer (problemático). O imperativo pragmático é o princípio da prudência que define a ação (ou bem enquanto meu bem) como o que é útil a minha felicidade (hipotético) e que é naturalmente desejado por todos (assertório). O imperativo da moralidade define o bem moral considerado em si mesmo ou a ação humana enquanto boa em si mesma (por isso é categórico).
\end{abstract}

(SALGADO, 2012, p. 131-132)

\title{
4.6 Possibilidades dos Imperativos
}

Os imperativos são juízos práticos e só são possíveis por uma questão somente de lógica que desconsidera dados da Antropologia, da Psicologia ou da Metafísica.

O imperativo categórico é a chave de explicação de todo o edifício da filosofia prática de Kant. Nas palavras de Salgado: "para o imperativo, a justificação se faz na medida em que é explicitada a origem do Sollen que ele expressa, ou da vinculação que cria para o ser racional" (SALGADO, 2012, p. 132).

Immanuel Kant recorre ao conceito de juízo sintético a priori para responder àpergunta de como o imperativo é possível. Assim como também recorreu a tal juízo quando justificava a possibilidade das ciências (da matemática, física e metafísica) na "Crítica da Razão Pura". Todo imperativo é, pois, juízo que acrescenta conhecimento, sintético, mas dado a priori, ou seja independente da experiência concreta.

\subsection{Os Imperativos Hipotéticos}

Os imperativos hipotéticos são juízos analíticos e se revelam na seguinte proposição: "quem quer o fim deve querer o meio para alcançá-lo". Tais imperativos visam a um fim. Logo, tanto o imperativo técnico como o pragmático são imperativos hipotéticos, uma vez que o primeiro visa à destreza e o segundo à felicidade.

De acordo com Salgado, ainda que Kant se mostre inseguro quanto à natureza prática do imperativo hipotético, se eles são imperativos, hão de ser práticos. 
Verifica-se que a vontade humana é sempre o elemento que define o fim. E "se o elemento vontade aparece como origem de uma obra, trata-se de atividade prática passível do comando do imperativo" (SALGADO, 2012, p. 134).

Por fim, no Direito positivo, o imperativo hipotético aparece como norma jurídica e funciona como "esquema da aplicação dos princípios a priori do direito" (SALGADO, 2012, p. 134).

\subsection{O Imperativo Categórico e sua Possibilidade e Fórmulas de Escrita}

Em relação ao imperativo categórico, Kant não demonstra nenhum tipo de dúvida quanto à sua natureza prática, uma vez que é uma proposição prática que expressa o Sollen.

Diferentemente do imperativo hipotético, o imperativo categórico não condiciona a vontade diante de um fim, mas é o próprio fim da ação. O imperativo categórico é um juízo sintético a priori. Nesse sentido, o professor Salgado afirma:

\footnotetext{
O imperativo categórico é sintético e a priori; sintético porque a ligação da minha máxima com a lei moral não está incluída previamente na vontade; e a priori porque não decorre da experiência, pois essa ligação (entre vontade e ação) é universal e necessária. (SALGADO, 2012, p. 136)
}

Nos juízos sintéticos a priori, não é a experiência o terceiro elemento que liga o sujeito com o predicado que lhe é acrescentado, e o que torna possível a existência de tais juízos é a intuição pura (caracterizada pela idealidade do tempo e do espaço).

No imperativo categórico, o elemento que possibilita o encontro entre a obrigação emanada do imperativo e a vontade é a liberdade. Somente é possível o agir humano sob o pressuposto da liberdade. A liberdade é o fundamento, o postulado da razão prática.

O imperativo categórico é um imperativo incondicional, pois está indissoluvelmente ligado a um conceito não empírico, e por isso é tão somente formal e consequentemente universal. Nele, o dever ser é expresso em sua plenitude.

O critério supremo do agir humano, ou seja, o imperativo categórico é o desdobramento da própria vontade pura como razão pura prática. Ele só é possível porque o ser humano pertence, simultaneamente, ao mundo sensível e ao mundo inteligível e manifesta-se como uma livre causalidade denominada vontade. Se o ser humano não fosse dotado de sensibilidade não teria sentido a existência do dever, nem de um comando a estabelecer o dever ser. Nas palavras de Immanuel Kant: 
Se eu fosse apenas um membro do mundo inteligível, minhas ações seriam conforme o princípio da autonomia. Se fosse membro do mundo sensível somente, minhas ações seriam conforme a heteronomia da natureza. (KANT, apud SALGADO, 2012, p. 137).

Em síntese, a possibilidade do imperativo categórico se dá pela existência do pressuposto da liberdade. Mas, não há condições de saber como é possível tal pressuposto nem como explicar como a razão pura pode ser prática e determinar a vontade.

A fórmula geral do imperativo categórico é: "Age apenas segundo a máxima, em virtude da qual possas querer ao mesmo tempo que ela se torne lei universal". A partir delas, Kant apresenta outras três:

1) Fórmula da universalidade ou igualdade: "Age de tal modo que a máxima da tua ação, através da sua vontade, se devesse tornar em lei universal da natureza"

2) Fórmula da humanidade: "Age de tal modo que uses a humanidade, tanto na tua pessoa como na pessoa de qualquer outro, sempre e ao mesmo tempo, como fim e nunca como meio simplesmente".

3) Fórmula da autonomia: "a tua vontade, através de suas máximas, se possa considerar ao mesmo tempo como legisladora universal." Essas três fórmulas expressam a ideia de justiça da obra de Kant, uma vez que são fundadas nas ideias de universalidade, humanidade e liberdade. Assim, Kant exprime o conceito de justiça numa bem sucedida teorização: "a partilha igual do bem maior do ser humano enquanto ser racional, a liberdade, que aparece como o conteúdo da ideia de justiça" (SALGADO, 2012, p. 141).

\subsection{Universalidade e Igualdade}

Salgado conclui sua exposição a respeito do pensamento moral de Kant na Crítica da Razão Prática levantando, sobretudo o problema da possibilidade de realização deste universal como, então, universal concreto. O homem é definitivamente um ser racional.

Contudo, Kant biparte esta realidade ao dizer que este mesmo ser racional atua em esfera sensível, isto é, sofre inclinações trazidas pelas suas sensações. Seria, então, possível a realização deste universal? Qual a resposta que Kant dá a esta aporia?

A lei moral exige ser universal. Somente a máxima de ação que pode ser elevada a categoria de lei é moralmente válida, não somente para quem a criou, mas para todo ser igualmente racional. A universalidade pressupõe a igualdade. O imperativo categórico é critério para aferir a validade moral da máxima. 
A filosofia grega buscou, trabalhando a busca de encontrar o uno no mutável, a semelhança na diferença, encontrar este universal. Era, ainda, abstrato, pois que extirpava de tudo o que não era idêntico a sim mesmo. Hegel fará o esforço de reconciliar o idêntico ediferente dialeticamente chegando, por assim dizer, a uma identidade da identidade e da não identidade, ideia. Neste momento é alcançado o universal concreto no homem, em si e para si, sempre na relação com o outro. É o eu que vê o outro e se torna "nós". Para alcançar esta conclusão, que só se chega ao pensar o pensamento, Hegel reúne aquilo que kant havia seperado em noumenon e phaenomenon, em última análise, reconciliar objeto e sujeito de maneira dialética.

Kant não alcança esta tarefa. A duplicidade do homem em sensível e racional impossibilita a realização do universal concreto no indivíduo. No ser humano realiza-se o universal enquanto abstrato, lei moral, de maneira puramente formal. A moralidade se concretiza através de postulados da razão, fora da esfera do ser humano enquanto vivente na Terra. Afirma Salgado:

É assim que o ideal do bem supremo,visto na perspectiva do indivíduo, nada mais é do que a tentativa de pensar o universal no indivíduo, mas que, para Kant, se tornou quase impossível, pela dificuldade de realizar-se nele a lei moral. Por isso foi necessário recorrer a algo que nele não se encontrava, ao postulado da existência de Deus para realizar o universal, o bem supremo. No indivíduo concreto deste mundo, o universal da lei moral realiza-se apenas em parte. (SALGADO, 2012, p. 143)

O bem supremo só se realizará no homem enquanto humanidade, coletividade. É a ideia de paz perpétua que traz esta realização do universal na comunidade humana. A paz perpétua, segundo Kant, só se realizará em uma comunidade universal de justiça, em meio as nações, na qual " a liberdade de todos é assegurada por leis que sejam como produto da vontade de todos" (SALGADO, 2012, p. 143). Salgado considera este esforço de realização do universal além de um "parentesco com Hegel” o "coroamento de sua filosofia"- de Kant.

Contudo, o pensador mineiro não considera esta resposta a solução da "questão da realização do universal”. Se o homem como indivíduo não realiza o universal, como pode realizá-lo enquanto espécie? Realizá-lo como espécie não seria suficiente para superar sua impossibilidade como indivíduo, ou seja, não o tornaria capaz de realizar o universal por si? Permanece, então, o impasse desta aporia filosófica.

Em última análise, este seria um "problema" do sistema filosófico de Kant que advém, originariamente, da bipartição da possibilidade de conhecimento entre noumenon e phaenomenon. A coisa em si o homem só sabe que existe; não pode conhecê-la. O que se conhece são os fenômenos que, embora subordinados à transcendentalidade do próprio homem, 
ou seja, à razão, estão também sujeitos ao sensível. Ainda que se considere que a aporia foi resolvida em termos comunitários, permanece a dúvida no tocante ao indivíduo.

Kant tenta superar o problema no direito, "onde o bem supremo seja responsabilidade só do homem, seu único garante"(SALGADO, 2012, p. 145).

Ainda assim pode-se afirmar que a filosofia kantiana é uma forma de buscar o universal. Ensina Salgado:

O mesmo princípio da Crítica da Razão Pura está presente na ordem moral: caminhar do particular para o universal ou impor a ordem ao particular pelo universal, como bem mostra a sua afirmação ,as intuições sem os conceitos são cegas $^{\text {ee }}$. Na filosofia prática o princípio é o mesmo: dar validade ao particular pelo universal. A ação do indivíduo sem a lei moral é cega, irracional, sem validade. Só o apelo a universalidade da lei moral pode conferir moralidade a ação individual.(SALGADO, 2012, p. 145)

Ressalte-se que este universal ainda esta em seu momento abstrato, regido pelo princípio da igualdade. Só se pode falar em universalidade do imperativo da lei moral enquanto tem como referência todos os seres racionais, tratados de maneira igual. Ou seja, a lei moral só é válida supondo-se a igualdade dos imperativos categóricos a quem ela se destina. $\mathrm{O}$ critério para aferir igualdade e universalidade é o mesmo: a razão (dado diferenciador do homem para outros animais).

Kant ressalta que a universalidade do imperativo categórico é a mesma que a da lei da natureza. São diferentes como o ser (Sein) se difere do dever ser (Sollen), porém seu resultado é tão necessário quanto. Nos dizeres de Salgado:

\footnotetext{
A mesma relação que existe entre um determinado fenômeno e a lei universal de dilatação do metal pelo calor deve existir também entre a ação que se pretende moral e o imperativo categórico. (SALGADO, 2012, p. 147)
}

Ainda assim é fundamental que haja, como suporte de universalidade do imperativo categórico, a vontade. Vontade não entendida como simples desejo subjetivo, de querer que amáxima seja universal, mas de poder querer que a máxima seja universal (wollen Können). Só se pode querer que a máxima seja universal quando ela não provém de experiências dos sentidos, mas sim de princípios da racionalidade. A universalidade como critério de validade no tratamento ao outro nada mais é do que a exigência de tratamento igual para todos, ideia de justiça formal. Considerar alguém como igual é tratá-lo como fim em si mesmo, em última análise, como livre. 


\section{CONCLUSÃO}

Se é possível, como afirma Joaquim Carlos Salgado, perquirir e encontrar uma Ideia de justiça na obra de Kant, certamente esta vincula-se umbilicalmente à noção de moral. Só é possível moral de um ser racional e livre. Uma vez racional o homem cria leis para si mesmo, de maneira necessária. A razão é legisladora por natureza, dela nada poderia sair senão leis.

Para ser moral tem de ser necessária e obrigatória, ou seja, universalizável e cogente. Nenhuma ação racional poderia agir contra si mesma, a própria razão.

Com esta elaboração Kant retira o fundamento da ação moral do ser humano que pensa, do ser racional, e não de nada fora dele. A ação moral é obrigatória porque racional e, sendo assim, o ser humano basta para fundamentar obrigatoriedade e necessidade de toda lei moral.

As leis jurídicas não têm seu fundamento completamente retirado do ser racional. Ela precisa da coerção do Estado para se tornar obrigatória. Porém toda lei jurídica deve fundamentar-se numa lei de cunho moral, ou seja, estar de acordo com os parâmetros que as leis morais estabelecem de liberdade e igualdade.

Na obra de Kant direito e moral são esferas muito bem distintas. Contudo, não há direito positivo possível fora da Ideia de justiça. Significa que não há direito positivo fundamentado no poder do Estado sem o arcabouço teórico que fundamenta a obrigatoriedade da moral no ser humano racional e em nada mais fora dele. 


\section{REFERÊNCIAS BIBLIOGRÁFICAS}

ALQUIÉ,FERDINAND.Critique delaraison pratique, ed. Puf, 7ªed, Paris, 2003.

BÍBLIA, Livro de Lucas. Bíbliasagrada. Edição contemporânea. Trad. João Ferreirade Almeida. Flórida: EditoraVida, 1994.

KERSTING,Wolfgang.“'OfundamentodevalidadedamoraledodireitoemKant”In“Kant

e oDireito", coordenador Alexandre TravessoniGomes, Mandamentos, $1^{\text {a }}$ ed. Belo Horizonte, 2009.

SALGADO,JoaquimCarlos.A ideiadejustiça em Kant: seufundamentonaliberdadee na igualdade. Ed. Del Rey, $3^{\text {a }}$ ed. Belo Horizonte, 2012.

VAZ,HenriqueCláudiodeLima.AformaçãodopensamentodeHegel.Ed.Loyola, $1^{\mathrm{a} e d .}$ São Paulo, 2014. 